\title{
İş Güvenliği Uzmanlarının İş Tatminleri Üzerine Bir Araştırma: Karadeniz Bölgesi Örneği
}

\author{
Abdullah Karakaya ${ }^{a}$, Volkan Sanci ${ }^{\mathrm{b}}$ \\ aKarabük Üniversitesi, İktisadi ve İdari Bilimler Fakültesi, Karabük. \\ ${ }^{b}$ Karabük Üniversitesi, Sosyal Bilimler Enstitüsü, Karabük.
}

\begin{abstract}
$\overrightarrow{\mathrm{O} z}$
Sanayileşmeyle birlikte makineleşmenin üretimde artan bir biçimde kullanılması, işletmelerde iş kazası ve meslek hastalıklarının da artmasına neden olmuştur. Dolayısıyla günümüzde iş kazası ve meslek hastalıkları sebebiyle yaşanan maddi ve manevi kayıpların önlenmesi adına iş săglığı ve güvenliği kültürü tüm kesimlerin üzerinde önemle durduğu bir konu haline gelmiştir. Bu çerçevede işyerini, işin niteliğini, üretim araçlarının işlevini bilen ve bunlara yönelik koruyucu güvenlik önlemlerini belirleyen iş güvenliği uzmanlarının etkin ve verimli olarak çalışabilmeleri için işten elde ettikleri tatminin kabul edilebilir düzeyde olması büyük önem taşımaktadır. Bu önemden hareketle Karadeniz Bölgesi özelinde iş güvenliği uzmanlarının iş tatmini düzeylerini belirlemek için yapılan bu çalışmada iş güvenliği uzmanlarının; işten elde ettikleri tatmin düzeyinin orta düzeyde olduğu tespit edilmiştir.
\end{abstract}

Anahtar Kelimeler: İş Tatmini, İş Güvenliği Uzmanı, Karadeniz Bölgesi.

\section{A Study on Job Satisfaction of Occupational Safety Experts: The Black Sea Region Case}

\begin{abstract}
With the industrialization, incereasingly use of mechanisation caused to increse work accidents and occupational diseases in organizations. Thereby, today occupational health and safety culture has become an important issue for all sectors on behalf of the prevention of financial and moral losses due to work accidents and occupational diseases. Being acceptable level of satisfaction of occupational safety experts, knowing the workplace, the nature of work, the function of the means of production and defining protective security measures for them, is of great importance. Moving from this importance, it was determined that the level of satisfaction of occupational safety experts, obtained from the work, is middele level in this study to determine their level of job satisfaction in the Black Sea Region.
\end{abstract}

Keywords: Job Satisfaction, Occupational Safety Experts, The Black Sea Region

\section{GíRiş}

Günümüzde yaşanan değişim, toplumsal alanda olduğu kadar iş yaşamında da önemli gelişmelere neden olmaktadır (Erol, 2010: 87). Bu değişimleri yakından yaşayan birey, bu gelişmelerin yarattığı evrensel sonuçların olumsuz etkileriyle savaşmakta zorlanırken, bedenen ve psikolojik olarak da çalışma hayatına özgü birçok etmen karşısında olumlu veya olumsuz bir biçimde etkilenebilmektedir (Aslantürk ve Şahan, 2012: 136). Bunun için, çalışanın beden ve ruh sağlığını korumak adına işyerinin fiziki

*Yazışma adresi. Email: volkansanci@karabuk.edu.tr 
yapısının iyileştirilmesi, zararlı etkenlerin ortadan kaldırılması ve önlenmesi, çalışana uygun iş ortamı oluşturulması büyük önem taşımaktadır (Aksu, 2012: 60).

Günümüz yoğun rekabet ve teknolojik gelişmelerin yaşandığ1 bir dönemde örgütlerin başarılarını etkileyen önemli faktörlerden biri çalışanlardır. Örgütler, çalışanlarının üstün performansları sayesinde kaliteli ürünler, yüksek satışlar, yüksek kar ve yatırım fırsatı yakalayabilirler (Akar ve Yıldırım, 2008: 98). Ancak teknolojinin hızla ilerlemesi, makineleşme, yeni üretim yöntemleri, işe yabancılaşma ve işyerine ait olma duygusunun zayıflaması gibi nedenler, örgütlerde iş kazaları ve meslek hastalıkları sonucunda yaşanan maddi ve manevi kayıpları ürkütücü boyutlara ulaştırmaktadır (Bıyıkcı, 2010: 1). Nitekim dünyada her 15 saniyede 1 işçi iş kazası veya meslek hastalı̆̆ı nedeniyle hayatını kaybederken, her 15 saniyede 160 işçi işle ilgili kaza geçirmektedir. İş kazası ya da işle ilgili hastalıklar sonucunda her gün 6.300 işçi, yılda ise 2.3 milyon işçi hayatını kaybetmektedir. Yılda 337 milyonu aşan iş kazası sonucunda işe devamsızlıklar artmaktadır (Kılkış ve Demir, 2012: 24). Böyle bir ortamda örgütte çalışmaktan mutlu olan iş güvenliği uzmanlarının rolü büyük önem arz etmektedir.

İş güvenliği uzmanı 6331 Sayılı Kanunda, iş sağlığı ve güvenliği alanında görev yapmak üzere Bakanlıkça yetkilendirilmiş, iş güvenliği uzmanlığı belgesine sahip mühendis, mimar veya teknik eleman biçiminde tanımlanmıştır (Narter, 2014: 52). Teknik elemandan kasıt, teknik öğretmen, fizikçi ve kimyager unvanına sahip olanlar ile üniversitelerin iş sağlığı ve güvenliği programı mezunlarıdır (Özdemir, 2014: 168). İş güvenliği uzmanları, çalışanların fiziksel ve zihinsel sağlıklarını koruma, daha verimli çalışabilmeleri için gereken güvenlik önlemlerini alma ve dolayısı ile çalışanların işletmedeki devamlılıklarını sağlama amacıyla çalışan, insan kaynağının etkin ve verimli kullanılması konusunda önemli bir rol üstlenmektedir (Tozkoparan ve Taşoğlu, 2011: 183). $\mathrm{Bu}$ paralelde, çalışanlar üzerindeki olası etkileri dikkate alındığında (Poyraz ve Kama, 2008: 144), iş güvenliği uzmanlarının iş tatmin düzeyinin yüksek olması, çalışanlara daha güvenli bir iş ortamı sağlanması, olumsuz iş davranışları, devamsızlık, işten ayrılma niyetini engellemesi ve en önemlisi çalışanların iş tatminini de olumlu yönde etkileyeceği düşünülmektedir. Bu çerçevede, çalışmada iş güvenliği uzmanlarının iş tatmin düzeyleri ve bunun demografik özelliklerine göre anlamlı farklılık gösterip göstermediği araştırılmıştır. Çalışmanın, iş güvenliği uzmanlarının bireysel ve örgütsel sorunlarına 1şık tutması bakımından ilgili literatüre zenginlik katacağı düşünülmektedir.

\section{1. İş Güvenliği Uzmanlarında İş Tatmini}

Bireyler yaşamlarının büyük bir bölümünü çalıştıkları yerlerde geçirmektedirler. $\mathrm{Bu}$ bağlamda iş tatmini, çalışanların ekonomik durumunun yanı sıra, psikolojik durumunu da yakından etkileyen önemli bir role sahiptir (Can vd., 2009: 229). Kavram olarak tatmin; elde edilen sonuçların beklentileri ne derece karşıladığı ile ilgili bir durum olarak tanımlanabilir (Demirdelen ve Ulama, 2013: 68). İş tatmini ise, bireyin herhangi bir işe veya göreve karşı olan olumlu duygusal tepkisi şeklinde ifade edilebilir (Demir vd., 
2008: 140). İş tatmini, örgütte çalışan çalışanlar tarafından taşınan özel bir davranış altkümesi olarak tanımlanabilir (Kitapçı ve Sezen, 2002: 220). İş tatminini, çalışanların iş tecrübeleri sonucunda elde ettiği olumlu ruh hali olarak tanımlamak mümkündür (Karataş ve Güleş, 2010: 75). Bu ruh hali bireylerin önceki iş yaşantılarına, beklentilerine ve sahip oldukları seçeneklere bağlı olan bir durumdur (Şahin, 2013: 13). Kavrama ilişkin tanımlamalardan da anlaşılacağı üzere iş tatmini, genel olarak çalışanın işinde ne kadar mutlu olduğunu ifade etmektedir (Bozkurt ve Bozkurt, 2008: 2).

İş tatminine ilişkin ilk araştırmalar 1930'lu yıllara dayanmaktadır (Gül vd., 2008: 1). Araştırmacılar farklı yönleri ile hem global bir yapı hem de bir kavram olarak tatmini tanımlamışlar ve ölçmüşlerdir (Poyraz ve Kama, 2008: 147). Bu çalışmalardan; Maslow'un ihtiyaçlar hiyerarşisi teorisi (1943, 1954), Herzberg'in çift faktör teorisi (1959), Alderfer'in varolma-ilişki-gelişme (ERG = VİG) teorisi (1972), Mc Clelland'ın başarı güdüsü teorisi (1988) kapsam teorileri olarak tanımlanmaktadır (Yüksel, 2005: 294). Vroom'un beklenti teorisi (1964), Lawler ve Porter'ın ümit (beklenti) teorisi (1968), Adams'ın eşitlik (ödül adaleti) teorisi (1963), Locke'nin değer ayrılığı teorisi (1976), Lawler'in çok yönlü tatmin teorisi (1973), Salancik ve Pfeffer'in sosyal enformasyon süreçlemesi $(1977,1978)$ ve genetik teoriler (Erdil vd., 2004: 18) ise süreç teorileri olarak adlandırılmaktadır.

Konuyla ilgili yapılmış araştırmalar, bireylerin iş tatmininde bireysel ve örgütsel faktörlerin etkili olduğunu ortaya koymaktadır (Karataş ve Güleş, 2010: 76). Buna göre bireysel faktörler; bireyin yapısı, duyguları, düşünceleri, istekleri ile içinde bulunduğu ihtiyaçlar ve bunların şiddet dereceleriyle ilgilidir (Kök, 2006: 293). Örgütsel faktörler arasında ise; ücret, yükselme fırsatları, işin doğası ve niteliği, çalışma şartları, iletişim ve işletme politikaları vb. bulunmaktadır (Yeşilyurt ve Koçak, 2014: 305).

İş tatmininin bireysel ve örgütsel açıdan bir dizi önemli sonuçları bulunmaktadır. Öncelikle, iş tatmini sorumluluk, görevin çeşitliliği ve iletişim gibi çalışma koşulları ile bağlantılıdır. Bununla birlikte, iş tatmini, devamsızlık, örgütsel etkisizlik ve verimlilik karşıtı davranışlar gibi sonuçlarla ilgili bulunmaktadır. Bu sorunlar ve bunların doğurduğu sorunlar doğrudan örgütle ilgilidir (Yüksel, 2005: 295-296). Dolayısıyla iş tatmininin yüksek olduğu durumlarda genellikle işten ayrılma niyetinin daha düşük olduğu görülmektedir (Çekmecelioğlu, 2006: 157). İş tatminsizliği ise çalışanların beklentileri yerine gelmediği zaman oluşur (Aksu, 2012: 61).

İş tatmini sağlayan örgütler, çalışanların ihtiyaç ve beklentilerini karşılayabilen, çalışan bulmakta zorlanmayan, çalışanların sürekli çalışmak istedikleri örgütlerdir. Bunun yanı sıra iş tatminini sağlayamayan ve çalışanların ihtiyaç ve beklentilerini karşılayamayan örgütler ise çalışan bulmakta zorlanan, iş gören devir hızı oranı yüksek olan ve buna bağlı olarak verimliliğin düştüğü örgütlerdir. Bütün bu sonuçlar, iş tatmininin örgütler açısından ne kadar hayati derecede önemli olduğunu göstermektedir (Üngüren vd., 2010: 2925). 


\section{Yöntem}

\subsection{Evren ve Örneklem}

Araştırmanın evrenini, Karadeniz Bölgesinde faaliyet gösteren 6667 iş güvenliği uzmanı oluşturmaktadır. Araştırmada iş güvenliği uzmanlarının demografik özellikleri ile işten elde ettikleri tatmin düzeyleri arasındaki farklılıklar incelenmeye çalışılmıştır. Dolayısıyla araştırmada "Karadeniz Bölgesinde faaliyet gösteren iş güvenliği uzmanlarının iş tatmini düzeyleri demografik özelliklerine göre farklılık göstermekte midir?" sorusuna cevap aranmaya çalışılmıştır. 2016 yılı Aralık ve 2017 yılı Ocak ayları arasında yapılan araştırmanın evrenini oluşturan iş güvenliği uzmanlarının özelliklerini temsil edebilecek örneklemin belirlenmesinde, gelişigüzel örnekleme yöntemi kullanılmıştır. Örneklem büyüklüğünün hesaplanmasında ise Krejcie ve Morgan (1970'ın önerdiği örneklem tablosundan yararlanılmıştır. Söz konusu tabloda, 0,05 anlamlılık düzeyi ve $\pm 0,05$ hata oranında, evren hacminin 6000-7000 olması halinde örneklem büyüklüğünün 361 olması gerektiği belirtilmiş olup araştırma kapsamına 379 kişi dâhil edilmiştir. Bu çerçevede araştırmaya dâhil edilen kişilerden $124^{\prime}$ ü 30 yaş ve altı, 119'u 3135 yaş arası, 80'i 36-40 yaş arası ve 56'sı 40 yaşın üzerindedir. Cinsiyet oranlarına göre 69'u kadınlardan ve 310'u da erkeklerden oluşmaktadır. Katılımcılardan 93'ü A grubu, 46'sı B grubu ve 240 gibi büyük bir çoğunluğu C grubu iş güvenliği belgesine sahiptir. Mesleki deneyim açısından incelendiğinde; 91'i 1 yıl ve altı, 161'i 2-10 yıl ve 127'sinin ise 10 yılın üzerinde mesleki deneyime sahip olduğu tespit edilmiştir.

\subsection{Veri Toplama Yöntemi}

Araştırmada online ve yüz yüze anket tekniği kullanılmış olup söz konusu anket iki bölümden oluşturulmuştur. Birinci bölümde, iş güvenliği uzmanlarının demografik özelliklerini belirleyebilmek için (yaş, cinsiyet, sahip oldukları iş güvenliği belgesi ve mesleki deneyim) dört soruya yer verilmiştir. Anketin ikinci bölümünde ise iş güvenliği uzmanlarının iş tatminini ölçmek için Weiss ve arkadaşları (1967) tarafından geliştirilen “Minnesota İş Tatmin Ölçeği”nin 20 soruluk kısa versiyonu kullanılmıştır. Söz konusu ölçek içsel, dışsal ve genel tatmin düzeyini ölçmeye yönelik olarak tasarlanmıştır. Buna göre içsel tatmini; faaliyet, serbestlik, değişiklik, sosyal statü, ahlaki değer, tanınma, kendi kendine bir şeyler yapabilme, otorite, yeteneklerini kullanma, sorumluluk, yaratıcilık, başarı $(1,2,3,4,7,8,9,10,11,15,16$ ve 20) ifadeler, dişsal tatmini; ilerleme, şirket politikası ve uygulaması, çalışma arkadaşları, çalışma şartları, güvence, ücret, yönetici-insan ilişkileri, yönetici ve teknik $(5,6,12,13,14,17,18$ ve 19.) ifadeler, genel tatmini ise ifadelerin tamamı oluşturmaktadır (Aksu, 2012: 66; Weiss vd., 1967: 4). Araştırmada kullanılan ölçeğin Cronbach's Alpha katsayısı $(\mathrm{a}=0,928)$ olarak tespit edilmiş olup bu oran $\alpha=0,70$ 'in üzerinde olduğundan (Kalayc1, 2010)'ya göre bu ölçeğin yüksek güvenilirlikte olduğu söylenebilir. İş tatminine ilişkin ifadeler 5'li Likert Ölçeği'nde çoktan seçmeli (1Kesinlikle Katılmıyorum; 5-Kesinlikle Katılıyorum) olarak yaygın kullanım şekliyle 
tasarlanmış olup uygulama sonrasinda yapılan elemeden sonra 379 anket değerlendirmeye alınmıştır.

\subsection{Verilerin Analizi}

Elde edilen veriler SPSS 20 for Windows paket programı kullanılarak analiz edilmiştir. “İş Tatmini Ölçeğin"e ilişkin ifadelerin faktör yükleri, Kaiser-Meyer-Olkin (KMO) ve güvenirlik analizi için Cronbach's Alpha değerleri saptanmıştır. Daha sonra verilerin normal dağılımına (Kolmogorov-Smirnov Test) ve homojenliğine ilişkin uygun testler yapılmıştır. Ancak p değerlerinin 0,05'ten küçük olduğu tespit edilmiş ve parametrik test koşulları sağlanmadığı için parametrik olmayan testlerden bağımsız iki grubun karşılaştırılmasında Mann-Whitney U Testi, birbirinden bağımsız ikiden fazla grubun karşılaştırılmasında Kruskal-Wallis H Testi ile araştırma amacına ulaşılmaya çalışılmıştır.

\section{Bulgular}

Araştırmanın bu kısmında, elde edilen veriler üzerinden ulaşılan sonuçlara yer verilmiştir. Bu kapsamda Tablo 1'de ölçeğin yapı geçerliğine ilişkin varimax rotasyonu ve temel bileşenler (principal components) yöntemi kullanılarak yapılan faktör analizi ve ifadelerin aritmetik ortalama değerleri sunulmuştur. 
Tablo 1. İş Tatminine Yönelik Faktör Analizi

\begin{tabular}{|c|c|c|c|c|c|}
\hline FAKTÖRLER & F. Y & Ö. D & A. $\mathrm{V}$ & \multicolumn{2}{|c|}{$\overline{\mathrm{X}} / \mathrm{SS}$} \\
\hline \multicolumn{6}{|l|}{ İçsel Tatmin } \\
\hline Beni her zaman memnun etmesi bakımından işimden memnunum & 917 & \multirow{12}{*}{8,866} & \multirow{12}{*}{44,330} & 3,17 & 1,43 \\
\hline Kişilere ne yapacaklarını söyleme şansına sahip olma bakımından işimden memnunum. & ,912 & & & 3,12 & 1,50 \\
\hline Başkaları için bir şeyler yapabilme olanağını bana vermesi bakımından işimden memnunum & ,906 & & & 3,21 & 1,39 \\
\hline Toplumda "şanslı bir kişi" olma fırsatı vermesi bakımından işimden memnunum & 899 & & & 3,22 & 1,36 \\
\hline Tek başıma çalışma olanağımın olması bakımından işimden memnunum & 898 & & & 3,27 & 1,34 \\
\hline Bana kendi kararlarımı uygulama serbestliği vermesi bakımından işimden memnunum & 894 & & & 3,04 & 1,51 \\
\hline Ara sıra değişik şeyler yapabilme şansım olması bakımından işimden memnunum & 869 & & & 3,10 & 1,31 \\
\hline Vicdanıma aykırı olmayan şeyler yapabilme şansım olması bakımından işimden memnunum & ,787 & & & 3,01 & 1,20 \\
\hline Bana sabit bir iş olanağı sağlaması bakımından işimden memnunum & 709 & & & 3,57 & 1,69 \\
\hline Kendi yeteneklerimi kullanarak işimi yapabilme şansı vermesi bakımından işimden memnunum & 674 & & & 2,69 & 1,25 \\
\hline Yaptığım iş karşılığında duyduğum başarı hissi bakımından işimden memnunum & 623 & & & 3,10 & 1,42 \\
\hline İşimi yaparken kendi yöntemlerimi kullanabilme şansı vermesi bakımından işimden memnunum & ,604 & & & 3,45 & 1,29 \\
\hline \multicolumn{6}{|l|}{ Dişsal Tatmin } \\
\hline Çalışma şartları bakımından işimden memnunum. & 911 & \multirow{8}{*}{5,756} & \multirow{8}{*}{28,778} & 3,06 & 1,45 \\
\hline İş ile ilgili alınan kararların uygulamaya konulması bakımından işimden memnunum. & ,897 & & & 2,91 & 1,41 \\
\hline Yaptığım iş ve karşılığında aldığım ücret bakımından işimden memnun değilim & 890 & & & 3,00 & 1,43 \\
\hline İş içinde terfi olanağının olması bakımından işimden memnunum & 881 & & & 2,87 & 1,32 \\
\hline Yaptığım iyi bir iş karşılığında takdir edilmem bakımından işimden memnunum & ,876 & & & 2,81 & 1,33 \\
\hline Çalışma arkadaşlarımın birbirleri ile anlaşmaları bakımından işimden memnunum & 874 & & & 2,70 & 1,29 \\
\hline Yöneticimin ekibindeki kişileri idare tarzı bakımından işimden memnun değilim & ,806 & & & 2,95 & 1,35 \\
\hline Yöneticimin karar vermedeki yeteneği bakımından işimden memnunum & 789 & & & 3,18 & 1,29 \\
\hline
\end{tabular}

Kaiser-Meyer-Olkin (KMO) $=0,933$

Bartlett testi: $\chi^{2}=8130,548 ; p=0,000$

*FY: Faktör Yükü, ÖD: Öz Değer, AV: Açıklanan Varyans 
Araştırmada elde edilen veriler üzerinde, temel bileşenler (principal components) yöntemi ve varimax rotasyonuna göre faktör analizi yapılarak iş güvenliği uzmanlarının iş tatmini boyutları ortaya çıkarılmaya çalışılmıştır. Kaiser-Meyer-Olkin örneklem yeterliliği, 0,933 ( $\mathrm{p}<.000)$, verinin faktör analizine uygun olduğunu göstermektedir. Kalaycı'ya (2010) göre bu değerler faktör analizi uygulamak için yeterli seviyede kabul edilmektedir. İş güvenliği uzmanlarının iş tatminini ölçen 20 ifade ile yapılan faktör analizinde, 2 faktör elde edilmiş olup bu iki faktörün toplam açıklanan varyans değeri \%73'tür. Eroğlu (2005)'de 350 ve üzerindeki veri sayısı için faktör ağırlığının 0,30 ve üzerinde olması gerektiğini belirttiğinden ve araştırmadaki ifadelere ilişkin tüm faktör yükleri belirtilen değerin üzerinde olduğundan faktör yükleri de kabul edilebilir seviyededir. Tablo 1'de görüldüğü üzere bu faktörlere giren ifadeler ve aldıkları faktör yükleri birbirleriyle anlamlı ve tutarlı bir şekilde kümeleştirilerek bu iki faktör sırasıyla içsel tatmin ve dişsal tatmin olarak isimlendirilmiştir. Ayrıca hem alt boyutların hem de genel ölçek güvenilirliğinin değerleri de 0,70'in üzerinde olduğu için ölçeklerin iç tutarlılık düzeylerinin yeterli olduğu (Kayış, 2009) söylenebilir.

Tablo 2. İş Güvenliği Uzmanlarının İş Tatmin Düzeylerinin Yaş Değişkenine Göre Karşılaştırılması (Kruskal-Wallis H Testi)

\begin{tabular}{|c|c|c|c|c|c|}
\hline Boyutlar & Yaş & $\mathbf{N}$ & M.R. & Chi-Square & $\mathbf{P}$ \\
\hline \multirow{4}{*}{ İçsel Tatmin } & 30 Yaş ve Altı & 124 & 119,35 & \multirow{4}{*}{2,431} & \multirow{4}{*}{0,488} \\
\hline & 31-35 Yaş Arası & 119 & 178,29 & & \\
\hline & 36-40 Yaş Arası & 80 & 194,54 & & \\
\hline & 41 Yaş ve Üstü & 56 & 187,70 & & \\
\hline \multirow{4}{*}{ Dişsal Tatmin } & 30 Yaş ve Altı & 124 & 209,90 & \multirow{4}{*}{7,572} & \multirow{4}{*}{0,056} \\
\hline & 31-35 Yaş Arası & 119 & 179,27 & & \\
\hline & 36-40 Yaş Arası & 80 & 190,69 & & \\
\hline & 41 Yaş ve Üstü & 56 & 167,76 & & \\
\hline \multirow{4}{*}{ Genel Tatmin } & 30 Yaş ve Altı & 124 & 205,46 & \multirow{4}{*}{4,626} & \multirow{4}{*}{0,201} \\
\hline & 31-35 Yaş Arası & 119 & 177,20 & & \\
\hline & 36-40 Yaş Arası & 80 & 192,23 & & \\
\hline & 41 Yaş ve Üstü & 56 & 179,78 & & \\
\hline
\end{tabular}

${ }^{*} p<0,05$

Tablo 2'ye göre, iş güvenliği uzmanlarının içsel $\left(X^{2}=2,431 ; p>0,05\right)$, dişsal $\left(X^{2}=7,572 ; p>0,05\right)$ ve genel $\left(X^{2}=4,626 ; p>0,05\right)$ tatmin düzeylerinin yaş değişkenine göre anlamlı bir farklılık gösterip göstermediğini belirlemek için yapılan analizde herhangi bir farklılık tespit edilmemiştir. Dolayısıyla içsel, dışsal ve genel tatmin boyutlarındaki yaş ortalamaları incelediğinde bütün ortalama değerlerin birbirine yakın olduğu söylenebilir. 
Tablo 3. İş Güvenliği Uzmanlarının İş Tatmin Düzeylerinin Cinsiyet Değişkenine Göre Karşılaştırılması (Mann-Whitney U Testi)

\begin{tabular}{|c|c|c|c|c|c|c|}
\hline Boyutlar & Cinsiyet & $\mathbf{N}$ & $\begin{array}{c}\text { Siralama } \\
\text { Değeri } \\
\text { Ortalaması }\end{array}$ & $\begin{array}{c}\text { Siralama } \\
\text { Değerleri } \\
\text { Toplamı } \\
\end{array}$ & $\begin{array}{c}\text { Mann- } \\
\text { Whitney U }\end{array}$ & $\mathbf{P}$ \\
\hline \multirow{2}{*}{ İçsel Tatmin } & Kadın & 69 & 193,13 & 13326,00 & \multirow{2}{*}{10479,000} & \multirow{2}{*}{0,793} \\
\hline & Erkek & 310 & 189,30 & 58684,00 & & \\
\hline \multirow{2}{*}{ Dişsal Tatmin } & Kadın & 69 & 180,04 & 12423,00 & \multirow{2}{*}{10008,000} & \multirow{2}{*}{0,403} \\
\hline & Erkek & 310 & 192,22 & 59587,00 & & \\
\hline \multirow{2}{*}{ Genel Tatmin } & Kadın & 69 & 189,17 & 13053,00 & \multirow{2}{*}{10638,000} & \multirow{2}{*}{0,945} \\
\hline & Erkek & 310 & 190,18 & 58957,00 & & \\
\hline
\end{tabular}

${ }^{*} p<0,05$

İş güvenliği uzmanlarının cinsiyetlerine göre içsel, dışsal ve genel tatminlerinin anlamlı bir farklılık gösterip göstermediğini belirleyebilmek için yapılan Mann-Whitney U testi sonuçları Tablo 3'te görülmektedir. Test sonuçlarına göre, kadın ve erkeklerin içsel tatmin ( $U=10479,0 ; p>0,05)$, dişsal tatmin $(U=17341,5 ; p>0,05)$ ve genel tatmin $(U=10638,0$; $\mathrm{p}>0,05)$ düzeylerinde anlamlı bir farklılık bulunamamıştır. Sıralama değeri ortalaması incelendiğinde, içsel, dışsal ve genel tatmin boyutlarında erkeklerin ve kadınların işten elde ettikleri tatmin düzeylerinin aynı olduğu söylenebilir.

Tablo 4. İş Güvenliği Uzmanlarının İş Tatmin Düzeylerinin İş Güvenliği Belgesi Değişkenine Göre Karşılaştırılması (Kruskal-Wallis H Testi)

\begin{tabular}{|c|c|c|c|c|c|}
\hline Boyutlar & í ISG Belgesi & $\mathbf{N}$ & M.R. & Chi-Square & $\mathbf{P}$ \\
\hline \multirow{3}{*}{ İçsel Tatmin } & A Grubu Belge & 93 & 187,85 & \multirow{3}{*}{0,048} & \multirow{3}{*}{0,977} \\
\hline & B Grubu Belge & 46 & 190,50 & & \\
\hline & C Grubu Belge & 240 & 190,74 & & \\
\hline \multirow{3}{*}{ Dişsal Tatmin } & A Grubu Belge & 93 & 212,83 & \multirow{3}{*}{5,819} & \multirow{3}{*}{0,054} \\
\hline & B Grubu Belge & 46 & 192,47 & & \\
\hline & C Grubu Belge & 240 & 180,68 & & \\
\hline \multirow{3}{*}{ Genel Tatmin } & A Grubu Belge & 93 & 199,63 & \multirow{3}{*}{1,115} & \multirow{3}{*}{0,573} \\
\hline & B Grubu Belge & 46 & 192,77 & & \\
\hline & C Grubu Belge & 240 & 185,74 & & \\
\hline
\end{tabular}

${ }^{*} p<0,05$

İş güvenliği uzmanlarının İSG belgelerine göre içsel, dışsal ve genel tatminlerinin anlamlı bir farklılık gösterip göstermediğini belirleyebilmek için yapılan Kruskal-Wallis H testi sonuçları Tablo 4 'te görülmektedir. Test sonuçlarına göre iş güvenliği uzmanlarının içsel $\left(X^{2}=0,048 ; p>0,05\right)$, dişsal $\left(X^{2}=5,819 ; p>0,05\right)$ ve genel tatmin $\left(X^{2}=1,115 ; p>0,05\right)$ düzeylerinin ISG belgesi değişkenine göre anlamlı bir farklılık göstermediği tespit 
edilmiştir. Dolayısıyla içsel tatmin, dışsal tatmin ve genel tatmin boyutlarındaki belge ortalamaları incelediğinde bütün ortalama değerlerin birbirine yakın olduğu söylenebilir.

Tablo 5. İş Güvenliği Uzmanlarının İş Tatmin Düzeylerinin Mesleki Deneyim Değişkenine Göre Karşılaştırılması (Kruskal-Wallis H Testi)

\begin{tabular}{|c|c|c|c|c|c|}
\hline Boyutlar & $\begin{array}{c}\text { Mesleki } \\
\text { Deneyim }\end{array}$ & $\mathbf{N}$ & M.R. & Chi-Square & $\mathbf{P}$ \\
\hline \multirow{3}{*}{ İçsel Tatmin } & 1 ve Alt1 & 91 & 211,29 & \multirow{3}{*}{6,603} & \multirow{3}{*}{$0,037^{*}$} \\
\hline & 2-10 Y1l Aras1 & 161 & 175,03 & & \\
\hline & 11 Yil ve Üstü & 127 & 193,72 & & \\
\hline \multirow{3}{*}{ Dişsal Tatmin } & 1 ve Alt1 & 91 & 215,79 & \multirow{3}{*}{6,901} & \multirow{3}{*}{$0,032^{\prime}$} \\
\hline & 2-10 Y1l Aras1 & 161 & 184,65 & & \\
\hline & $11 Y_{1} l$ ve Üstü & 127 & 178,30 & & \\
\hline \multirow{3}{*}{ Genel Tatmin } & 1 ve Alt1 & 91 & 215,81 & \multirow{3}{*}{8,058} & \multirow{3}{*}{$0,018^{*}$} \\
\hline & 2-10 Y1l Aras1 & 161 & 175,08 & & \\
\hline & $11 Y_{1} l$ ve Üstü & 127 & 190,43 & & \\
\hline
\end{tabular}

${ }^{*} p<0,05$

İş güvenliği uzmanlarının mesleki deneyimlerine göre içsel, dışsal ve genel tatminlerinin anlamlı bir farklılık gösterip göstermediğini belirleyebilmek için yapılan Kruskal-Wallis $H$ testi sonuçları Tablo 5 'te görülmektedir. Test sonuçlarına göre iş güvenliği uzmanlarının içsel $\left(X^{2}=6,603 ; p<0,05\right)$, dişsal $\left(X^{2}=6,901 ; p<0,05\right)$ ve genel tatmin $\left(X^{2}=8,058 ; p<0,05\right)$ düzeylerinin mesleki deneyim değişkenine göre anlamlı bir farklılık gösterdiği tespit edilmiştir. İçsel ve genel tatmin boyutundaki ortalama değerler incelendiğinde, tatmin düzeyi en fazla olan grubun 1 yıl ve altı olduğu, tatmin düzeyi en düşük olan grubun ise 2-10 yıldır çalışanlar olduğu söylenebilir. Dışsal tatmin boyutundaki ortalama değerler incelendiğinde, tatmin düzeyi en fazla olan grubun 1 yıl ve altı olduğu, tatmin düzeyi en düşük olan grubun ise 10 yılın üzerinde çalışanlar olduğu söylenebilir.

\section{SONUÇ VE ÖNERILER}

Sanayi sonrası toplum diye de adlandırılan bilgi toplumuyla birlikte üretim süreçlerinde insana bakış açısı da değişmiştir. İnsan günümüz üretim sürecinde en önemli faktör olup, sağlıklı ve güvenlikli bir ortamda çalışması sağlandığı takdirde işletmelere katma değer oluşturan bir faktör durumuna gelmiştir (Orhan, 2014: 73). Tüm dünyada olduğu gibi Türkiye'de de işletmelerde sağlıklı ve güvenlikli bir ortam oluşturma yolunda atılmış önemli adımlar vardır, ancak iş kazalarını önlemek için uygulamada neler yapılması gerektiği konusunda iş güvenliği uzmanlarının kılavuzluğuna ihtiyaç duyulduğu bir gerçektir (Arslan ve Ulubeyli, 2016: 1324). Bu sebeple iş güvenliği uzmanlarının çalışma koşullarının iyileştirilmesi, görev, yetki ve sorumluluklarını etkin bir şekilde yerine getirebilmeleri ve işten elde ettikleri tatmininin sağlanması büyük önem 
taşımaktadır. Bu kapsamda Karadeniz bölgesinde faaliyet gösteren iş güvenliği uzmanlarının iş tatmin düzeylerinin hangi düzeyde olduğu ve işten elde ettikleri tatminin yaş, cinsiyet, İSG belgesi ve mesleki deneyim değişkenleri ile olan ilişkisi değerlendirilmeye çalışılmıştır.

Araştırma sonucunda, iş güvenliği uzmanlarının içsel tatmin düzeylerinin genel olarak orta düzeyde olduğu tespit edilmiştir. Nitekim iş güvenliği uzmanları, yaptıkları işin kendilerini her zaman meşgul etmesinden, çalışanlara ne yapacaklarını söyleyebilme şanslarının olmasından, başkaları için bir şeyler yapabilme olanaklarından, toplumda "şanslı bir kişi" olma fırsatı vermesinden kısmen memnun oldukları saptanmıştır. İş güvenliği uzmanları, tek başına çalışabilme olanaklarının olmasından, kendi kararlarını uygulayabilme serbestliğinden, değişik şeyler yapabilme şanslarının olmasından, vicdanlarına uyarak bir şeyler yapabilme şanslarının olmasından kısmen memnun olduklarını belirtmişlerdir. İş güvenliği uzmanları, sabit bir işlerinin olmasından memnuniyet duyarken, kendi yeteneklerini kullanabilme şansından, yaptı̆̆ iş karşılığında duyduğu başarı hissinden, iş yaparken kendi yöntemlerini kullanabilme şanslarının olmasından dolayı kısmen memnun oldukları söylenebilir.

Analizler sonucunda, iş güvenliği uzmanlarının dışsal tatmin düzeylerinin de genel olarak orta düzeyde olduğu tespit edilmiştir. Dolayısıyla iş güvenliği uzmanlarının, çalışma şartlarından, işle ilgili alınan kararların uygulanabilirliğinden, yaptıkları iş karşılığında aldıkları ücretten, terfi olanaklarının olmasından, yaptıkları iyi bir iş karşılığında takdir edilmelerinden kısmen memnun oldukları saptanmıştır. Ayrıca iş güvenliği uzmanlarının, çalışma arkadaşlarıyla kurdukları ilişkilerden, yönetici veya işverenin yönetim tarzı ile karar verme yeteneğinden kısmen memnun oldukları tespit edilmiştir.

Araştırmada, iş güvenliği uzmanlarının içsel, dişsal ve genel tatmin düzeylerinin yaş değişkenine göre anlamlı bir farklılık gösterip göstermediğini belirlemek için yapılan analizde herhangi bir farklılık tespit edilmemiştir. Dolayısıyla içsel, dışsal ve genel tatmin boyutlarındaki yaş ortalamalarının birbirine yakın olduğu saptanmıştır. Elde edilen bulgulara göre, kadın ve erkeklerin içsel, dişsal ve genel tatmin düzeylerinde anlamlı bir farklılık bulunamamıştır. Sıralama değeri ortalaması bakımından içsel, dışsal ve genel tatmin boyutlarında erkeklerin ve kadınların işten elde ettikleri tatmin düzeylerinin aynı olduğu söylenebilir. Araştırmada iş güvenliği uzmanlarının içsel, dişsal ve genel tatmin düzeylerinin İSG belgesi değişkenine göre anlamlı bir farklılık göstermediği tespit edilmiştir. Dolayısıyla içsel tatmin, dışsal tatmin ve genel tatmin boyutlarındaki belge ortalama değerlerin birbirine yakın olduğu bulunmuştur. İş güvenliği uzmanlarının mesleki deneyimlerine göre içsel, dişsal ve genel tatminlerinin anlamlı bir farklılık gösterip göstermediği analiz edilmiştir. Test sonuçlarına göre iş güvenliği uzmanlarının içsel, dişsal ve genel tatmin düzeylerinin mesleki deneyim değişkenine göre anlamlı bir farklılık gösterdiği tespit edilmiştir. İçsel ve genel tatmin boyutundaki ortalama değerler 
incelendiğinde, tatmin düzeyi en fazla olan grubun 1 yıl ve altı olduğu, tatmin düzeyi en düşük olan grubun ise 2-10 yıldır çalışanlar olduğu söylenebilir. Dişsal tatmin boyutundaki ortalama değerler incelendiğinde, tatmin düzeyi en fazla olan grubun 1 yıl ve altı olduğu, tatmin düzeyi en düşük olan grubun ise 10 yılın üzerinde çalışanlar olduğu saptanmıştır.

Araştırmadan elde edilen sonuçlar göstermektedir ki iş güvenliği uzmanlarının iş tatminlerini artırıcı politika ve stratejilerin geliştirilmesi gerekmektedir. İş güvenliği uzmanları, ISG uygulamalarının en yakın takipçisi ve uygulayıcısı olarak kendilerini bağımsız ve işverenin müdahalesine maruz kalmamalarını sağlayacak bir biçimde yetkilendirilmelidirler. İşverenler, iş güvenliği uzmanlarının tek başlarına çalışabilecekleri, kendi kararlarını, yeteneklerini ve yöntemlerini uygulayabilecekleri bir iş ortamı sağlamak durumundadırlar. Ayrıca iş güvenliği uzmanlarına ekonomik anlamda kendilerini rahat hissedebilecek bir ücretin verilmesi, işletmenin etkinliği ve verimliliği açısından büyük önem taşımaktadır.

$\mathrm{Bu}$ araştırma zaman ve ekonomik kısıtlar nedeniyle Karadeniz Bölgesiyle sınırlı tutulmuştur. Bundan sonra yapılacak benzer çalışmalara tüm bölgelerimizin dâhil edilmesi, ilgili tüm paydaşlar açısından önemli sonuçlar gösterebilecektir.

\section{KAYNAKÇA}

Akar, C. ve Yıldırım, T. Y. (2008) “Yöneticilerin Örgütsel Bağlılık, İş Tatmini ve Rol Stres Kaynakları Arasındaki İlişkiler: Yapısal Denklem Modeliyle Beyaz Et Sektöründe Bir Alan Uygulaması", Gazi Üniversitesi İktisadi Ve İdari Bilimler Fakültesi Dergisi, 10 (2), 97-113.

Aksu. N. (2012) “İş Tatmininin Bazı Demografik Değişkenler Açısından İncelenmesi”, Polis Bilimleri Dergisi, 14 (1), 59-79.

Arslan, V. ve Ulubeyli, S. (2016) “İş Güvenliği Uzmanlarının Sorunlarına Yönelik Bir Saha Araştırması", Çalışma ve Toplum, 3, 1321-1340.

Bıyıkcı, E. T. (2010) İş Sağlığı ve Güvenliğinin Sağlanmasında İş Güvenliği Uzmanlığı, Bursa: Uludağ Üniversitesi, Sosyal Bilimler Enstitüsü, Yayınlanmamış Yüksek Lisans Tezi.

Bozkurt, Ö. ve Bozkurt, İ. (2008) “İş Tatminini Etkileyen İşletme İçi Faktörlerin Eğitim Sektörü Açısından Değerlendirilmesine Yönelik Bir Alan Araştırması," Doğuş Üniversitesi Dergisi, 9 (1), 1-18.

Can, Y., Soyer, F. ve Bayansalduz, M. (2009) “Sporcuların İş Tatmini İle Lider Bağlılığı ve Örgütsel Bağlılık Duyguları Arasındaki İlişkilerin İncelenmesi," Nĭğde Üniversitesi Beden Eğitimi Ve Spor Bilimleri Dergisi, 3 (3), 228-238.

Çekmecelioğlu, H. (2006) "İş Tatmini ve Örgütsel Bağlılık Tutumlarının İşten Ayrılma Niyeti ve Verimlilik Üzerindeki Etkilerinin Değerlendirilmesi: Bir Araştırma," "İş, Güç" Endüstri İlişkileri ve Insan Kaynakları Dergisi, 8 (2), 153-168.

Demir, H., Usta, R. ve Okan, T. (2008) “İçsel Pazarlamanın Örgütsel Bağlllık ve İş Tatminine Etkisi,” H.Ü. İktisadi ve İdari Bilimler Fakültesi Dergisi, 26 (2), 135-161. 
Demirdelen, D. ve Ulama, Ş. (2013) “Demografik Değişkenlerin Kariyer Tatminine Etkileri: Antalya' da 5 Yıldızlı Otel İşletmelerinde Bir Araştırma," İşletme Bilimi Dergisi, 1 (2), 65-89.

Erdil, O., Keskin, H., İmamoğlu, Z. S. ve Erat, S. (2004) “Yönetim Tarzı ve Çalışma Koşulları, Arkadaşlık Ortamı ve Takdir Edilme Duygusu İle İş Tatmini Arasındaki İlişkiler: Tekstil Sektöründe Bir Uygulama," Doğ $u$ ş Üniversitesi Dergisi, 5 (1), 17-26.

Gül, H., Oktay, E. ve Gökçe, H. (2008) “İş Tatmini, Stres, Örgütsel Bağlllık, İşten Ayrılma Niyeti ve Performans Arasındaki İlişkiler: Sağlık Sektöründe Bir Uygulama," Akademik Bakış, (15), 111.

Kalaycı, Ş. (2010). SPSS Uygulamalı Çok Değişkenli İstatistik Teknikleri, 5. Baskı, Ankara: Asil Yayın Dağıtım.

Karataş, S. ve Güleş, H. (2010) “ílköğretim Okulu Öğretmenlerinin İş Tatmini İle Örgütsel Bağlılığ1 Arasındaki İlişki," Uşak Üniversitesi Sosyal Bilimler Dergisi, 3 (2), 74-89.

Kayış, A. (2009). Güvenirlik Analizi. Şeref Kalaycı (Editör), SPSS Uygulamalı Çok Değişkenli İstatistik Teknikleri. Ankara: Asil Yayın Dağıtım.

Kılkış, İ ve Demir, S. (2012) “İşverenin İş Sağlığı ve Güvenliği Eğitimi Verme Yükümlülüğü Üzerine Bir İnceleme", Çalışma İlişkileri Dergisi, 3 (1), 23-47.

Kitapçı, H. ve Sezen, B. (2002) “Çalışanların Tatminini Belirleyici Unsurlar Üzerine Bir Araştırma: Kariyer Süreci Örneği," Fırat Üniversitesi Sosyal Bilimler Dergisi, 12 (1), 219-230.

Kök, B. S. (2006) “İş Tatmini ve Örgütsel Bağlllı̆̆ın İncelenmesine Yönelik Bir Araştırma,” İktisadi ve İdari Bilimler Dergisi, 20 (1), 291-317.

Krejcie, R. V. ve Morgan, D. W. (1970) “Determining Sample Size for Research Activities", Educational and Psychological Measurement, 30, 607-610.

Narter, S. (2014) İş Sağlı̆̆ı ve Güvenliğinde İdari, Cezai ve Hukuki Sorumluluk, Ankara: Adalet Yayınevi.

Orhan, S. (2014/2) “İş Güvenliği Uzmanlarının İş Güvencesi Sorunu”, HAK-İŞ Uluslararası Emek ve Toplum Dergisi, 3 (6), 70-89.

Özdemir, E. (2014) İşs Să̆lığı ve Güvenliği Hukuku, İstanbul: Vedat Kitapçılık.

Poyraz, K. ve Kama, B. (2008) “Algılanan İş Güvencesinin, İş Tatmini, Örgütsel Bağl1lık ve İşten Ayrılma Niyeti Üzerindeki Etkilerinin İncelenmesi", Süleyman Demirel Üniversitesi, İktisadi ve İdari Bilimler ve Fakültesi Dergisi, 13 (2), 143-164.

Şahin, S. (2013) “Gençlik Hizmetleri ve Spor İl Müdürlerinin İş Doyumu ve Örgütsel Bağlılıkları Arasındaki İlişkinin İncelenmesi," NWSA-Sports Sciences, 8 (1), 12-25.

Tozkoparan, G. ve Taşoğlu, J. (2011) İş Sağlığı ve Güvenliği Uygulamaları İle İlgili İşgörenlerin Tutumlarını Belirlemeye Yönelik Bir Araştırma", Uludă̆ Üniversitesi İktisadi ve İdari Bilimler Fakültesi Dergisi, 30 (1), 181-209.

Üngüren, E., Doğan, H., Özmen, M. ve Tekin, A. Ö. (2010) “Otel Çalışanlarının Tükenmişlik ve İş Tatmin Düzeyleri İlişkisi," Journal Of Yasar University, 17 (5), 2922-2937. 
Yeşilyurt, H. ve Koçak, N. (2014) "İş Doyumu ve Örgütsel Vatandaşlık Davranışı Arasındaki İlişkinin Otel İşletmeleri Açısından İncelenmesi," Dokuz Eylül Üniversitesi Sosyal Bilimler Enstitüsü Dergisi, 16 (2), 303-324.

Yüksel, İ. (2005) “İletişimin İş Tatmini Üzerindeki Etkileri: Bir İşletmede Yapılan Görgül Çalışma,” Doğuş Üniversitesi Dergisi, 6 (2), 291-306. 